\title{
NOT FOR PUBLICATION
}

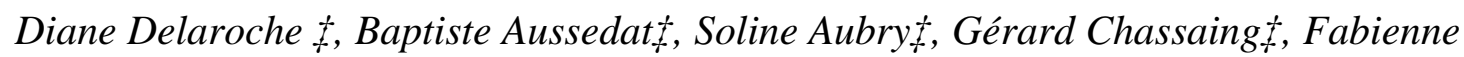
Burlina $\ddagger$, Gilles Clodic§, Gérard Bolbach $¥ \S$, Solange Lavielleł and Sandrine Sagan $¥ *$

Université Pierre et Marie Curie-Paris 6, UMR 7613, Paris, France ; CNRS, UMR 7613, "Synthèse, Structure et Fonction de Molécules Bioactives", Paris, France; FR 2769, UMR 7613, Paris, France ; Case courrier 182, 4, place Jussieu, 75005 PARIS, France. §Université Pierre et Marie Curie-Paris6, Plateforme de Spectrométrie de Masse et Protéomique, Paris, F75005 France.

TRACKING A NEW CELL-PENETRATING PEPTIDE, (RW)9, THROUGH AN ENZYME-STABLE MASS SPECTROMETRY REPORTER TAG

Supporting Information. This material gives the Table 1 showing differences in uptake with experimental parameters, describes the chemical synthesis of the trifluoroacetyl- $(\alpha, \alpha$ diethyl)Glycine group and the protocol of cell uptake used in this study.

\section{Experimental Procedures}

Standard Boc amino acids and Fmoc amino acids, p-methylbenzhydrylamine-polystyrene resin $\quad\left(1.26 \mathrm{mmol} \quad \mathrm{NH}_{2} / \mathrm{g}\right) \quad$ and $\quad$ O-(benzotriazol-1-yl)-1,1,3,3-tetramethyluronium hexafluorophosphate (HBTU) were purchased from Senn Chemicals. Other reagents for amino acid couplings were obtained from Applied Biosystems.

Chemical synthesis of the trifluoroacetyl-( $\alpha, \alpha$-diethyl)Glycine - Although the synthesis of this modified amino acid was already described [38], we have proceeded by an other chemical 
strategy. Briefly, ethyl N-((4-chlorophenyl)methylene)-glycinate was prepared according to the procedure reported by O'Donnell et al. [39].

Dialkylation of the imine: The procedure was analogous to that used by Ayoub, $\mathrm{M}$. $\mathrm{PhD}$ thesis, UPMC (1996). The imine $(10 \mathrm{mmol})$ was dissolved in DMSO $(20 \mathrm{ml})$ in the presence of $\mathrm{NaH}(11 \mathrm{mmol})$, the resulting mixture was stirred under Ar atmosphere. After $30 \mathrm{~min}, 1-$ bromoethane $(10 \mathrm{mmol})$ was added for $2 \mathrm{~h}$. This process was repeated twice to achieve dialkylation. At the end of the first alkylation, $\mathrm{NaH}(11 \mathrm{mmol})$ was added to the resulting mixture and let to react for $30 \mathrm{~min}$. 1-Bromoethane $(10 \mathrm{mmol})$ was added, after $2 \mathrm{~h}$ stirring, the reaction was quenched with acetic acid and ether $(50 \mathrm{ml})$ was added. The organic layer was washed three times with $50 \mathrm{ml}$ of saturated aqueous $\mathrm{NaCl}$, dried over $\mathrm{MgSO}_{4}$, filtered and the solvent was removed under vacuum. This compound was used without further purification.

Aldimine hydrolysis: The resulting imine was stirred with $1 \mathrm{~N} \mathrm{HCl}(15 \mathrm{ml})$ in THF $(15 \mathrm{ml})$ at $0^{\circ} \mathrm{C}$ for $90 \mathrm{~min}$. THF was removed under vacuum and the aqueous layer washed twice with ether $(2 \times 50 \mathrm{ml})$ and then lyophilized. This product was used without further purification.

Saponification: The resulting amino-ester was dissolved in acetonitrile/ $\mathrm{H}_{2} \mathrm{O}(10 \mathrm{ml}, 1 / 1)$ and LiOH (22 mmol) was added. After overnight stirring, the solvent was removed to dryness and $12 \mathrm{~N} \mathrm{HCl}$ was added, leading to the chlorhydrate of the free amino acid. This compound was purified by ion-exchange chromatography (Sephadex) using $0.2 \mathrm{~N}$ aqueous $\mathrm{NH}_{4} \mathrm{OH}$ for the elution. The collected fractions were lyophilized to afford ( $\alpha, \alpha$-diethyl)-Glycine. Trifluoroacetylation and crystallization of ( $\alpha, \alpha$-diethyl)Gly were performed according to the procedure of Tanaka et al. (yield $=30 \%$ over 4 steps) [38]. The ( $\alpha, \alpha$-diethyl)Glycine was characterized by ${ }^{1} \mathrm{H}-\mathrm{NMR}$ : 0.8-0.86 (6H, m, alkyl) ; 1.88-1.97 (2H, q, alkyl) ; 2.48-2.56 (2H, q, alkyl) ; 7.22-7.30 (1H, s, NH). 
This chemical strategy was also applied to the synthesis of deuterated $(\alpha, \alpha--$ diethyl)Glycine starting from deuterated 1-bromoethane (yield $=30 \%$ over 4 steps).

Peptide synthesis- Trifluoroacetyl-( $\alpha, \alpha$-diethyl)Gly-Lys( $\mathrm{N}_{\varepsilon}$ biotin)-(D)Lys-Cys-( $\left.\mathrm{RW}_{9}\right)$ or ${ }^{\mathrm{msr}}\left(\mathrm{RW}_{9}\right)$ sequence was synthesized by SPPS. Biotin is used for purification of the peptide after cell lysis $[26,27]$. The diethylglycine is incorporated either as the hydrogen- $\left(\mathrm{C}_{4} \mathrm{H}_{10}\right)$ or deuterium- $\left(\mathrm{C}_{4}{ }^{2} \mathrm{H}_{10}\right)$ containing forms to allow quantification of the peptide inside the cells by MALDI-TOF MS [26, 27]. The D-lysyl residue has been incorporated to confer enzyme unsensitiveness to the mass tag peptide. The cysteinyl residue was added to allow further coupling via a disulfide bridge of the CPP to a cargo. The peptides were synthesized in a stepwise manner on a $0.1 \mathrm{mmol}$ scale on a synthesizer (Applied Biosystems) using standard protocols of Boc chemistry (amino acid activation with DCC/HOBt). After removal of the Boc group, Boc-(L)-Lys(2-ClCbz) and Fmoc-(D)-Lys(Boc) were coupled manually by adding to the peptidyl-resin 5-fold excess of activated biotin (HBTU) in a mixture of DMF/DIEA. Fmoc protecting group was then removed by treating peptidyl-resin with a solution of piperidine (20\% in N-methyl-2-pyrrolidone). Then, trifluoroacetyl-( $\alpha, \alpha-$ diethyl)Glycine $\left({ }^{1} \mathrm{H}\right.$ or ${ }^{2} \mathrm{H}$ form) was activated by HATU in a mixture of DMF/DIEA and coupled (3-fold) excess to the Lys $\alpha$-amino group for $2 \mathrm{~h}$ at $50^{\circ} \mathrm{C}$. Finally, after Boc deprotection, 5-fold excess of activated Biotin (HBTU) was coupled to the Lys $\varepsilon$-amino group. The peptides were cleaved from the resin with anhydrous $\mathrm{HF}\left(2 \mathrm{~h}, 0^{\circ} \mathrm{C}\right)$ in the presence of anisole $(1.5 \mathrm{ml} / \mathrm{g}$ resin $)$, dimethylsulfide $(0.25 \mathrm{ml} / \mathrm{g}$ resin $)$ and thioanisole $(0.36 \mathrm{mg} / \mathrm{g}$ resin). The peptides were purified by reverse-phase HPLC on a C8 column using a linear gradient of acetonitrile in aqueous solution of $0.1 \%$ trifluoroacetic acid. The peptides were obtained with a purity $>95 \%$ (analytical HPLC) and then characterized by MALDI-TOF MS. The $\mathrm{m} / \mathrm{z}$ values of the protonated peptides for the hydrogen and deuterium forms are, 
respectively, 2307.4 and 2317.6. The disulfide bond in the conjugate ${ }^{\mathrm{msr}}(\mathrm{RW})_{9} / \mathrm{PKCi}$ (MW=4405.9) was synthesized as described [28].

Uptake assays - The uptake experiments were performed as previously described [24]. Cells for uptake were seeded in 12-well plates at a density of 500,000-1,000,000 cells per well in 2 ml medium with $10 \%$ FCS, the day before. Briefly, the biotinylated ${ }^{1} \mathrm{H}$-peptide $(7.5 \mu \mathrm{M})$ in $1 \mathrm{ml}$ of culture medium was incubated with adherent $\mathrm{CHO}$ cells $\left(10^{6}\right.$ cells per well) for 75 min at $37^{\circ} \mathrm{C}$. After washes with DMEM, the cells were treated with $500 \mu \mathrm{l}$ of a $0.05 \%$ trypsin, $0.02 \%$ EDTA solution for $3 \mathrm{~min}$ at $37^{\circ} \mathrm{C}$. The trypsin activity was stopped by addition of 100 $\mu \mathrm{l}$ of Soybean trypsin inhibitor $(5 \mathrm{mg} / \mathrm{ml})$ and $100 \mu \mathrm{l}$ of BSA $(1 \mathrm{mg} / \mathrm{ml})$. The cell suspension was then transferred in an Eppendorf tube and centrifuged at $3000 \mathrm{rpm}$ for $2 \mathrm{~min}$ at $4^{\circ} \mathrm{C}$. The pellet was washed with $1 \mathrm{ml}$ of $50 \mathrm{mM}$ Tris- $\mathrm{HCl}$ buffer $\mathrm{pH} 7.4,0.1 \%$ BSA and centrifuged again. It was resuspended in a lysis solution $(150 \mu 1,0.3 \%$ Triton $\mathrm{X} 100,1 \mathrm{M} \mathrm{NaCl})$ with the adequate amount of biotinylated ${ }^{2} \mathrm{H}$-peptide $[26,27]$. After a thermic shock at $100^{\circ} \mathrm{C}$ for 15 min, the cell lysate was centrifuged at $10,000 \mathrm{rpm}$ for $5 \mathrm{~min}$ at $4^{\circ} \mathrm{C}$. The pellet was washed with $750 \mu \mathrm{l}$ of $50 \mathrm{mM}$ Tris-HCl buffer $\mathrm{pH} 7.4,0.1 \%$ BSA, $3 \mathrm{mM}$ DTT and recentrifuged. The supernatants were collected and incubated with $100 \mu \mathrm{g}$ of streptavidin-coated magnetic beads for $2 \mathrm{~h}$ at $4^{\circ} \mathrm{C}$.

\section{References}

(38) Tanaka, M.; Imawaka, N.; Kurihara, M.; Suemune, H. Helv. Chim. Acta 1999, 82, 494-510.

(39) (39) O'Donnell, M. J.; Bennett, W. D.; Bruder, W. A.; Jacobsen, W. N.; Knuth, K.; LeClef, B.; Polt, R. L.; Bordwell, F. G.; Mrozack, S. R.; Cripe, T. A. J. Am. Chem. Soc. 1988, $110,8520-8525$. 
Table 1- Differences in uptake with experimental parameters. In conditions 1 and 2, ${ }^{\mathrm{msr}}(\mathrm{RW})_{9} \quad$ was incubated with cells for the indicated time. By contrast, in condition 3, ${ }^{\mathrm{msr}}(\mathrm{RW})_{9}$ was added twice to the cells, once for 18 hours and a second concentration was added for an additional $75 \mathrm{~min}$. For this latter condition, washings were done only before the first addition of peptide.

\begin{tabular}{|c|c|c|c|c|c|c|}
\hline $\begin{array}{c}\text { Exp. } \\
\text { Condit. }\end{array}$ & $\begin{array}{l}\text { Cell culture } \\
\text { time in } \\
\text { DMEM + } \\
10 \% \text { FCS }\end{array}$ & $\begin{array}{c}\text { Washings } 2 \mathrm{x} \\
2 \mathrm{ml} \\
\text { DMEM }\end{array}$ & $\begin{array}{l}\text { Incubation } \\
\text { time with } \\
{ }^{\mathrm{msr}}(\mathrm{RW})_{9} \\
(7.5 \mu \mathrm{M})\end{array}$ & $\begin{array}{l}\text { Intracell. } \\
\text { Peptide } \\
. \mu \mathrm{M})\end{array}$ & $\begin{array}{l}\text { Extracell. } \\
\text { Peptide } \\
. \mu \mathrm{M})\end{array}$ & $\begin{array}{c}\text { Intra } \\
/ \\
\text { Extra }\end{array}$ \\
\hline 1 & $15-20 \mathrm{hrs}$ & Yes & $75 \mathrm{~min}$ & $25 \pm 2$ & $2.4 \pm 0.3$ & 10 \\
\hline 2 & $15-20 \mathrm{hrs}$ & Yes & $18 \mathrm{hrs}$ & $3.8 \pm 0.5$ & $1.1 \pm 0.3$ & 3.5 \\
\hline 3 & $15-20 \mathrm{hrs}$ & $\begin{array}{c}\text { Yes } \\
+ \\
+ \\
\text { no }\end{array}$ & $\begin{array}{c}18 \mathrm{hrs} \\
+ \\
75 \mathrm{~min}\end{array}$ & 26 & Not determ. & Not determ. \\
\hline
\end{tabular}

